\title{
Hemipseudoathetosis due to a hemorrhage at the cervicomedullary junction
}

回舟

Figure CT scan and follow-up T2-weighted MRI
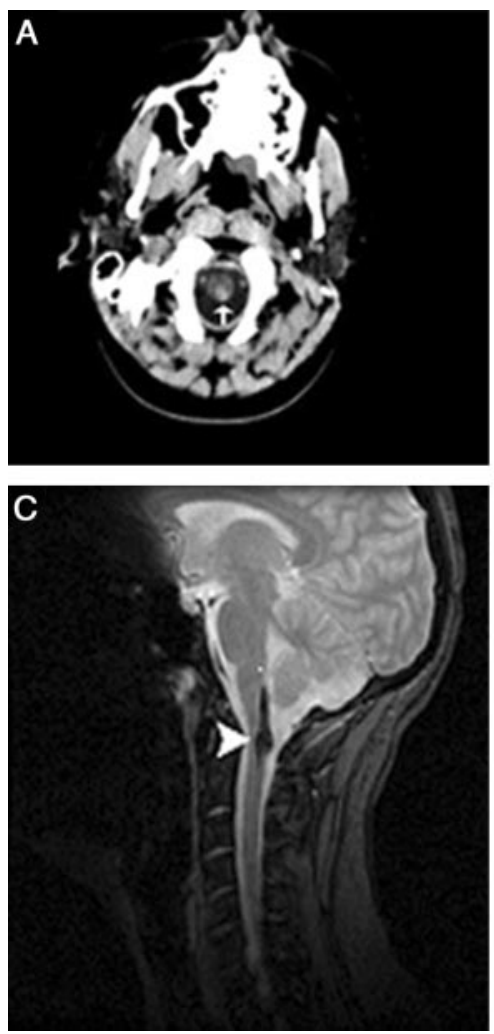

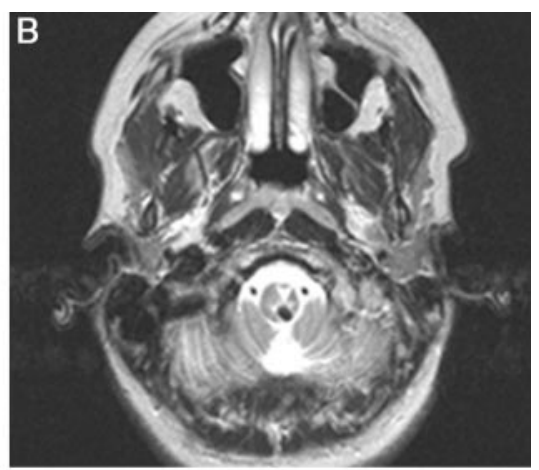

D

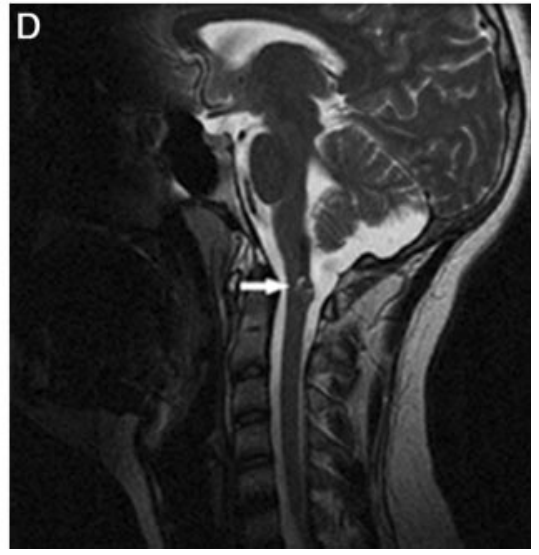

CT scanning revealed a hyperdense region at the cervicomedullary junction ( $A$, vertical arrow) suggesting acute hemorrhage, confirmed by the corresponding hypointensity most pronounced on T2-weighted MRI (B). Follow-up T2-weighted MRI demonstrated hemosiderin deposition (gradient echo, C) and a "popcorn"-like structure (D).
Supplemental data at www.neurology.org
A 17-year-old male presented with spontaneous left neck pain and ipsilateral involuntary arm movements. Examination revealed left facial hypoesthesia, right-sided pyramidal signs, and proprioceptive loss in the left arm with pseudoathetosis (video). Cervical-spinal imaging suggested acute hemorrhage at the cervicomedullary junction (figure, A and B). The patient improved over 3 months, and a follow-up MRI demonstrated hemosiderin deposition and a "popcorn" appearance confirming old intraparenchymal hemorrhage (figure, C and D).

The hemorrhage correlated anatomically with the left cuneate tract and nucleus. Coexisting signs implied involvement of the spinal tract and nucleus of the trigeminal nerve and the corticospinal tract predecussation. Pseudoathetosis indicates disruption of the proprioceptive pathway, from peripheral nerve to parietal cortex. ${ }^{1}$ Spontaneous cervicomedullary hemorrhage results from bleeding diatheses, tumor, syrinx, or vascular malformation. ${ }^{2}$

\section{Marc Gotkine, MBBS (Hons) John Moshe Gomori, MD, Jerusalem, Israel}

Disclosure: The authors report no conflicts of interest.

Address correspondence and reprint requests to Dr. Marc Gotkine, Department of Neurology, Hadassah University Hospital, Hebrew University-Hadassah Medical School, Jerusalem, Israel; marc@gotkine.com

1. Ghika J, Bogousslavsky J. Spinal pseudoathetosis: a rare, forgotten syndrome, with a review of old and recent descriptions. Neurology 1997;49:432-437.

2. Pullarkat VA, Kalapura T, Pincus M, Baskharoun R. Intraspinal hemorrhage complicating oral anticoagulant therapy: an unusual case of cervical hematomyelia and a review of the literature. Arch Intern Med 2000;160:237-240. 


\section{Neurology}

\section{Hemipseudoathetosis due to a hemorrhage at the cervicomedullary junction Marc Gotkine and John Moshe Gomori \\ Neurology 2007;69;1551 \\ DOI 10.1212/01.wnl.0000285506.04246.c2}

\section{This information is current as of October 8, 2007}

\author{
Updated Information \& \\ Services \\ Supplementary Material \\ References \\ Permissions \& Licensing \\ Reprints
}

including high resolution figures, can be found at: http://n.neurology.org/content/69/15/1551.full

Supplementary material can be found at: http://n.neurology.org/content/supp1/2007/10/05/69.15.1551.DC1

This article cites 2 articles, 1 of which you can access for free at: http://n.neurology.org/content/69/15/1551.full\#ref-list-1

Information about reproducing this article in parts (figures,tables) or in its entirety can be found online at:

http://www.neurology.org/about/about_the_journal\#permissions

Information about ordering reprints can be found online:

http://n.neurology.org/subscribers/advertise

Neurology ${ }^{\circledR}$ is the official journal of the American Academy of Neurology. Published continuously since 1951, it is now a weekly with 48 issues per year. Copyright . All rights reserved. Print ISSN: 0028-3878. Online ISSN: 1526-632X.

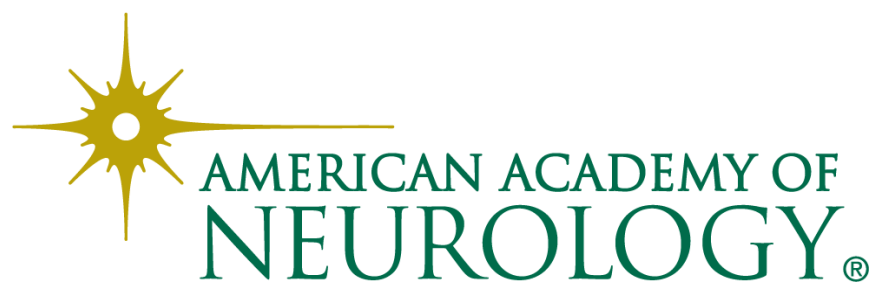

